\title{
Lymph Node Capsule
}

National Cancer Institute

\section{Source}

National Cancer Institute. Lymph Node Capsule. NCI Thesaurus. Code C33028.

The dense connective tissue that surrounds a lymph node. 